УДК 343.14

DOI https://doi.org/10.32782/2524-0374/2020-7/90

\title{
ПРОБЛЕМНІ ПИТАННЯ ДОПУСТИМОСТІ ДОКАЗІВ У КРИМІНАЛЬНОМУ ПРОВАДЖЕННІ
}

\section{PROBLEMATIC ISSUES OF ADMISSIBILITY OF EVIDENCE IN CRIMINAL PROCEEDINGS}

\author{
Завидняк В.І., д.ю.н., доцент, \\ професор кафедри кримінального процесу та криміналістики \\ Університет державної фіскальної служби Украйни
}

Шильнікова А.О., студентка магістратури Навчально-науковий інститут права Університету державної фіскальної служби Украӥни

На підставі аналізу літературних джерел, а також відповідних положень чинного Кримінального процесуального кодексу України у статті досліджено поняття та сутність доказів і їх допустимості як гарантії забезпечення конституційних прав, свобод і законних інтересів кожного учасника кримінального провадження, захисту від неправомірних дій органів, які здійснюють кримінальне провадження, та ухвалення справедливого, законного і обґрунтованого рішення суду.

Виявлено, що серед науковців немає єдиної точки зору щодо сутності категорії допустимості доказів, підстав виключення доказів із кримінального процесу. Водночас прийняття законних і обґрунтованих процесуальних рішень можливе лише тоді, коли вони ґрунтуються на перевірених і правильно оцінених відомостях, одержаних відповідно до вимог кримінально-процесуального закону.

Аналіз визначень різних вчених і практиків дозволив зробити висновок, що допустимість $€$ однією з юридичних властивостей доказів, що характеризується з точки зору законності джерела відомостей про факти. Розглянуто критерії допустимості доказів шляхом аналізу та синтезу наукових підходів з цього питання. На основі проведеного аналізу до них запропоновано відносити: 1) належний суб'єкт, збирання доказів; 2) належне процесуальне джерело; 3) належну процедуру отримання та фіксації доказів.

Досліджено зарубіжний досвід визнання доказів допустимими у кримінальному процесі. На підставі аналізу кримінальних процесуальних норм деяких зарубіжних країн вказано, що положення щодо допустимості доказів вже багато років існують у зарубіжному законодавстві. Досліджено основні проблемні моменти щодо допустимості доказів та умов їх отримання. Зазначено, що тільки доказ, отриманий відповідно до процесуальної форми, набуває такої внутрішньої властивості як допустимість.

Зроблено висновок, що єдиним суб'єктом, до компетенції якого належить вирішення питання визнання таких фактичних даних недопустимими, повинен бути суд, який здійснює судовий розгляд кримінального провадження. Зазначено, що питання щодо допустимості доказів потребує подальшого осмислення, узагальнення існуючих теоретичних напрацювань, розробки пропозицій стосовно вдосконалення цього інституту.

Ключові слова: докази, допустимість доказів, недопустимість доказів, критерії допустимості доказів, кримінальне провадження.

Based on the analysis of literature sources, as well as the relevant provisions of the current Criminal Procedure Code of Ukraine, the article examines the concept and essence of evidence and its admissibility as a guarantee of ensuring the constitutional rights, freedoms and legitimate interests of each participant in criminal proceedings, protection from illegal actions of bodies conducting criminal proceedings and the adoption of a fair, lawful and justified Court decision.

It is revealed that there is no single point of view among scientists regarding the essence of the category of admissibility of evidence, the grounds for excluding evidence from criminal proceedings. At the same time, the adoption of legal and justified procedural decisions is possible only when they are based on verified and correctly evaluated information obtained in accordance with the requirements of the Criminal Procedure Law.

Analysis of the definitions of various scientists and practitioners allowed us to conclude that admissibility is one of the legal properties of evidence, characterized from the point of view of the legality of the source of information about facts, as well as ways and means of fixing it. The criteria for the admissibility of evidence are considered by analyzing and synthesizing scientific approaches on this issue and based on the analysis carried out, it is proposed to include: 1 ) a proper subject, collecting evidence; 2) a proper procedural source; 3 ) a proper procedure for obtaining and fixing evidence.

The article examines the foreign experience of recognizing evidence as admissible in criminal proceedings. Based on the analysis of criminal procedural norms of some foreign countries, it is indicated that provisions on the admissibility of evidence have existed in foreign legislation for many years. The main problematic points regarding the admissibility of evidence and the conditions for obtaining it are investigated. It is noted that only evidence obtained in accordance with the procedural form acquires such an internal property as admissibility.

It is concluded that the only subject whose competence includes resolving the issue of recognizing such factual data as inadmissible as evidence should be the court that conducts judicial consideration of criminal proceedings. At the end of the article, it is noted that the issue of the admissibility of evidence requires further understanding, generalization of existing theoretical developments and development of proposals for improving this institution.

Key words: evidence, admissibility of evidence, inadmissibility of evidence, criteria for admissibility of evidence, criminal proceedings.

Постановка проблеми. Демократичні перетворення, які відбуваються в Україні, передбачають укріплення законності в усіх сферах державної і громадської діяльності. Однією $з$ таких сфер є кримінальне судочинство, яке має здійснюватися на основі точного та неухильного дотримання процесуальних норм. Винесення суддею законного та обгрунтованого судового рішення $\epsilon$ результатом з'ясування судом обставин, що мають значення для справи. Зазначені обставини повинні бути підтверджені відповідними доказами. Проте КПК передбачає, що при ухваленні судового рішення суд не може посилатися на докази, що є недопустимими (ч. 2 ст. 86). Це зумовлює актуальність дослідження питання допустимості доказів, які покладаються в основу судового рішення.

Проблему допустимості доказів досліджували такі вчені у галузі кримінального процесу та криміналістики: А.В. Панова [4], О.В. Ряшко [5], Л.М. Лобойко [5], М.А. Погорецький [7], О. Толочко [9], П.В. Руда [14] та інші дослідники.

Метою статті $\epsilon$ дослідження питання допустимості доказів у кримінальному провадженні. 
Виклад основного матеріалу. Чинний Кримінальний процесуальний кодекс України (далі - КПК, Кодекс) концептуально змінив порядок кримінального провадження, запровадив низку нових правових інститутів та механізмів їх реалізації [1]. Зокрема, у Кодексі вперше закріплена глава «Докази і доказування» та передбачені параграфи, які містять поняття «доказів», вимоги до належності та допустимості доказів, процесу доказування тощо. У ньому вперше визначено поняття «допустимості доказів» як одну із юридичних властивостей.

Відповідно до КПК «доказами у кримінальному провадженні є фактичні дані, отримані у передбаченому цим Кодексом порядку, на підставі яких слідчий, прокурор, слідчий суддя і суд встановлюють наявність чи відсутність фактів та обставин, що мають значення для кримінального провадження та підлягають доказуванню (ч. 1 ст. 84)» [1].

Я.Ю. Конюшенко під доказами розуміє будь-які відомості про факти, отримані у встановленому законом порядку органами дізнання, досудового слідства, прокуратури й суду для підтвердження чи спростування події злочину, з'ясування, відтворення та доведення обставин, які мають значення для встановлення істини та зумовлюють прийняття законних і обгрунтованих рішень [2].

На думку П.В. Жовтан, «доказами у кримінальному процесі $€$ нерозривна єдність фактичних даних (тобто відомостей про ті обставини, які підлягають доведенню) i їx джерел, які введені до кримінального процесу у передбаченій процесуальній формі відповідно до вимог чинного законодавства, на підставі яких орган дізнання, слідчий і суд встановлюють наявність або відсутність суспільно-небезпечного діяння, винність особи, яка вчинила це діяння, та інші обставини, що мають значення для правильного вирішення справи» [3].

Докази можуть бути отримані в результаті слідчих (розшукових) і негласних слідчих (розшукових) дій, регламентованих КПК України. Більшість порушень правил, які регламентують проведення слідчих (розшукових) дій і негласних слідчих (розшукових) дій, виключають можливість визнання отриманих доказів допустимими [4].

У ст. 86 чинного КПК України закріплено, що доказ визнається допустимим, якщо він отриманий у порядку, встановленому цим Кодексом. Законодавче закріплення положень щодо допустимості доказів та визнання їх недопустимими $€$ гарантією забезпечення конституційних прав, свобод та законних інтересів кожного учасника кримінального провадження, їх захисту від неправомірних дій і зловживання владою особами, які здійснюють кримінальне провадження, дотримання належної процедури та ухвалення законного, обгрунтованого і справедливого рішення суду [5].

Науковці дають визначення поняттю «допустимості» здебільшого через перелік критеріїв (або умов) допустимості. Так, Л.М. Лобойко розуміє під допустимістю доказів дозвіл для органу чи посадової особи, яка веде кримінальний процес, у силу положень процесуального права використати їх як докази. Автор наголошує, що допустимість доказу визначається з огляду на обставини його отримання і залучення до справи. На його думку, умовами допустимості доказів $є$ такі: 1) одержання фактичних даних із належного процесуального джерела; 2) одержання фактичних даних належним суб'єктом; 3) одержання фактичних даних у належному процесуальному порядку; 4) належне оформлення джерела фактичних даних [6, с. 132].

М.А. Погорецький під допустимістю доказів розуміє таку внутрішньо властиву їм якість, внаслідок якої ці докази здатні встановити обставини, що необхідні для повного і правильного вирішення певної справи, а вимога належності охоплює не весь доказ, а лише його змістовну частину - фактичні дані. Сукупність вимог, які висуває закон до процесу отримання доказів, становить інститут процесуальної допустимості, який полягає в тому, що належні до справи фактичні дані повинні бути одержані зі встановленого законом джерела уповноваженим на це суб'єктом кримінального процесу (органом дізнання, слідчим чи судом) і закріплені у спосіб, передбачений у кримінально-процесуальному законі [7].

Автори Науково-практичного коментаря КПК під допустимістю доказів розуміють їх придатність для використання у кримінальному процесі за формою, виділяючи такі ії критерії: законність джерела, законність способу отримання доказів, процесуальне оформлення ходу і результатів проведення слідчих (розшукових) і негласних (розшукових) дій, належний суб'єкт, який має право проводити процесуальні дії з отримання доказів [8, с. 253].

Аналіз визначень різних вчених-процесуалістів і практиків дозволив зробити висновок, що допустимість $\epsilon$ однією з юридичних властивостей доказів, яка характеризується з точки зору законності джерела відомостей про факти, способів і засобів іiі закріплення.

На думку О. Толочко, допустимість доказу визначається за такими критеріями: доказ повинен бути отриманий належним суб'єктом; доказ повинен бути отриманий із належного джерела; доказ повинен бути отриманий із дотриманням належної правової процедури; доказ не повинен бути отриманий на підставі неприпустимого доказу; доказ повинен містити дані, походження яких відомо і які можуть бути перевірені; силу доказу, який перевіряється, не повинна перевищувати небезпеку несправедливого упередження [9].

На основі проведеного аналізу пропонуємо до критеріїв допустимості віднести: 1) належний суб' єкт, збирання доказів; 2) належне процесуальне джерело; 3) належну процедуру отримання та фіксації доказів.

Говорячи про міжнародну практику в питаннях допустимості доказів, можна зустріти досить розбіжні точки зору. Так, КПК Республіки Казахстан 1997 року встановив, що фактичні дані повинні бути визнані недопустимими в якості доказів, якщо вони отримані з порушенням вимог Кодексу (КПК) шляхом позбавлення або утиску гарантованих державою прав учасників процесу при досудовому розслідуванні або в судовому розгляді справи вплинули чи могли вплинути на достовірність отриманих фактичних даних (ч. 1 ст. 116 КПК Республіки Казахстан) [10].

КПК Молдови передбачає, що допустимими є віднесені до справи переконливі та корисні докази, отримані відповідно до цього Кодексу [11]. Лише один критерій допустимості про те, що кожен законно зібраний доказ $€$ допустимим, виділяється у кримінальному процесуальному праві Франції [12]. Законодавство Німеччини визначає обов'язковий зв'язок доказу і факту та необхідну обов'язкову форму закріплення про те, що такий доказ повинен містити певне судження про факт і мати спеціально встановлену процесуальним законом форму [13].

У доказовому праві США для кожного з видів джерел доказів притаманні свої правила їх допустимості. В американському процесі допустимість доказів (admissibility) означає, що доказ може бути внесений на розгляд суду, лише якщо він має доказове значення (доказову силу) для доведення певного факту під час судового процесу $[14$, c. 42$] .3$ огляду на важливість виконання встановлених процедурних правил їх збирання та забезпечення дотримання законності при цьому є лише вторинною умовою допустимості. Це випливає 3 положення, закріпленого правилом 402 Федеральних правил доказування США, згідно з яким усі належні докази є допустимими, якщо інше не передбачено Конституцією США, актами Конгресу, цими правилами або розпорядженнями Верховного Суду США, винесеними відповідно до його нормотворчої компетенції. Неналежні докази $є$ недопустимими.

В основу рішення може бути покладений будь-який доказ тільки тоді, коли його достовірність не підлягає сумніву. Суд зобов'язаний перевіряти законність, повноту 
і правильність способу отримання доказів і відхиляти ті 3 них, які були одержані зі значними непоправними порушеннями встановлених умов. Допустимість доказу насамперед встановлюється з урахуванням обставин його отримання і залучення до справи, для чого необхідно з'ясувати джерело походження інформації та виявити можливість її перевірки й спростування.

Зміст фактичних даних повинен бути надійним, здійснюватися у законний спосіб, а при їх отриманні повинна бути дотримана відповідна процесуальна форма, оскільки ч. 3 ст. 62 Конституції України встановлює, що обвинувачення не може грунтуватися на доказах, одержаних незаконним шляхом, а також на припущеннях. Усі сумніви щодо доведеності вини особи тлумачаться на ії користь У ч. 3 ст. 17 КПК визначено презумпцію невинуватості людини про те, що підозра, обвинувачення не можуть грунтуватися на доказах, отриманих незаконним шляхом. Однак потрібно також враховувати ч.ч. 2, 3 ст. 88 КПК, де встановлено окремі випадки допустимості доказів. Тобто, доказ, отриманий відповідно до процесуальної форми, набуває такої внутрішньої властивості як допустимість.

Слід зазначити, що КПК України 2012 року хоча і містить ст. 86, у якій визначено поняття «допустимості доказів», але не виділяє, за винятком ст. 87 КПК України (недопустимість доказів, отриманих внаслідок істотного порушення прав і свобод людини), критерії вирішення питання про недопустимість доказів, даючи можливість зробити висновок, що не будь-яке порушення норм КПК тягне за собою визнання доказів недопустимими. Недопустимими може визнати докази тільки суд, причому чітких критеріїв для визнання доказів недопустимими КПК України не передбачає. Однак деякі науковці вважають, що незначні порушення кримінального процесуального закону не можуть бути підставою для визнання доказів недопустимими.

Важкою для трактування правозастосовників $\epsilon$ ч. 2 ст. 86 КПК, яка закріплює, що недопустимий доказ не може бути використаний при прийнятті процесуаль- них рішень, на нього не може посилатися суд при ухваленні судового рішення. Наведена норма породжує низку питань, адже ч. 1 ст. 89 КПК встановлює, що суд вирішує питання допустимості доказів під час їх оцінки в нарадчій кімнаті під час ухвалення судового рішення. Тому визнати доказ недопустимим може тільки суд. Тоді чи повинен слідчий або прокурор давати оцінку цьому доказу як недопустимому або суд має право залишати його поза увагою, як його взагалі не можна використовувати? Чи повинен прокурор представляти всі докази, в тому числі отримані із порушенням закону, адже вони все одно будуть визнані судом недопустимими?

Норма, яка міститься в ч. 1 ст. 94 КПК України, встановлює перелік суб'єктів, у яких є повноваження оцінювати кожен доказ з точки зору його допустимості. 3 цього приводу особливу увагу правників привертають слідчий суддя та суд. Перший із них здійснює свої повноваження під час досудового розслідування, другий - після його закінчення. Однак необхідно звернути увагу на ч. 4 ст. 87 , ст. 89 КПК України, текст яких вказує лише на одного суб'єкта - тільки суд під час судового засідання уповноважений визнавати докази недопустимими. Вважаємо, що єдиним суб'єктом, до компетенції якого належить вирішення питання визнання таких фактичних даних недопустимими, є суд, який здійснює судовий розгляд кримінального провадження.

Висновки. Отже, деякі норми КПК України 2012 року i нині у багатьох науковців-процесуалістів і практиків викликають дискусію, однак що стосується доказів, то в чинному кодексі вперше виділили, охарактеризували їх властивості та систематизували джерела доказів. Однак доводиться констатувати, що, незважаючи на легальне визначення поняття «доказу» та «допустимості доказу», умови (критерії) допустимості доказів і недопустимості доказів у чинному КПК не систематизовані, що потребує подальшого дослідження, узагальнення існуючих теоретичних напрацювань, розробки пропозицій стосовно вдосконалення.

\section{ЛITEPATУРA}

1. Кримінальний процесуальний кодекс України : Закон України від 13.04.2012 № 4651-VI. URL: https://zakon.rada.gov.ua/laws/ show/4651-17(дата звернення: 16.09.2020).

2. Конюшенко Я.Ю. Поняття доказів у кримінально-процесуальному провадженні, їх зміст і класифікація. Право України. 2010. № 3. С. 232-237.

3. Жовтан П.В. Щодо визначення поняття доказу у кримінальному процесі. Наукові записки Львівського університету бізнесу та права. 2013. Вип. 11. С. 275-279. URL: http://nbuv.gov.ua/UJRN/Nzlubp_2013_11_70 (дата звернення: 25.09.2020).

4. Ряшко О.В. Деякі проблемні питання щодо значення та умов допустимості отримання доказів у кримінальному процесі. Науковий вісник Львівського державного університету внутрішніх справ. Серія: Юридична. 2013. C. 428-436. URL: http://nbuv.gov.ua/UJRN/ Nvlduvs $2013 \quad 4 \quad 48$ (дата звернення: 14.09.2020).

5. Панова А.В. Визнання доказів недопустимими у кримінальному провадженні : монографрія. Харків : Право, 2017. 256 с.

6. Лобойко Л.М. Кримінальний процес : підручник. К. : Істина, 2014. 432 с.

7. Погорецький М.А. Функціональне призначення оперативно-розшукової діяльності у кримінальному процесі : монограсія. X., 2007.

8. Кримінальний процесуальний кодекс України : наук.-практ. комент. у 2 т. Ред.: В.Я. Тацій, В.П. Пшонка. Харків : Право, 2012. T. 1.768 c.

9. Толочко О. Гуманізація доказування у кримінальному провадженні. Науковий часопис Національної академії прокуратури України. 2014. № 4. C. 187-196. URL: http://www.chasopysnapu.gp.gov.ua/chasopys/ua/pdf/4-2015/tolochko.pdf (дата звернення: 19.09.2020).

10. Кримінально-процесуальний кодекс Республіки Казахстан. Закон Республіки Казахстан від 13.12.1997 № 207-1. URL: http://online.zakon.kz/Document/?doc_id=1008442\&doc_id2=1008442\#sub_id=1000002279\&sub_id2=1160000\&sel_link=1000002279 (дата звернення: 01.02.2020).

11. Уголовно-процессуальный кодекс Республики Молдова : Закон Республики Молдова от 14 марта 2003 года № 122-XV. URL: http://continent-online.com/Document/?doc_id=30397729 (дата звернення: 03.08.2020).

12. Elliott C., Vernon C., Jeanpierre E. Frenh Legal System. 2nd ed. Harlow, 2006. P. 219. URL: https://www.ulapland.Moader aspx?id=f27bd93f-52a1-482c-ad4e-ee252ffc90e6 (дата звернення: 21.09.2020).

13. Introduction to German Law / Editors: M. Reimann, J. Zekoll. Hague, 2005. P. 436. URL: https://www.law.umich.edu/library/guests/ pubsfaculty/facultypages/Pages/reimann_math ias.aspx (дата звернення: 15.10.2020).

14. Руда Т.В. Належність і допустимість доказів у цивільному процесі США та України: порівняльно-правовий аналіз. Вісник Верховного Суду України. 2009. № 12(112). С. 40-45. 